\title{
Skills and the graduate recruitment process: Evidence from two discrete choice experiments
}

Citation for published version (APA):

Humburg, M., \& van der Velden, R. K. W. (2014). Skills and the graduate recruitment process: Evidence from two discrete choice experiments. ROA. ROA Research Memoranda No. 002

https://doi.org/10.26481/umaror.2014002

Document status and date:

Published: 01/01/2014

DOI:

10.26481/umaror.2014002

Document Version:

Publisher's PDF, also known as Version of record

\section{Please check the document version of this publication:}

- A submitted manuscript is the version of the article upon submission and before peer-review. There can be important differences between the submitted version and the official published version of record.

People interested in the research are advised to contact the author for the final version of the publication, or visit the DOI to the publisher's website.

- The final author version and the galley proof are versions of the publication after peer review.

- The final published version features the final layout of the paper including the volume, issue and page numbers.

Link to publication

\footnotetext{
General rights rights.

- You may freely distribute the URL identifying the publication in the public portal. please follow below link for the End User Agreement:

www.umlib.nl/taverne-license

Take down policy

If you believe that this document breaches copyright please contact us at:

repository@maastrichtuniversity.nl

providing details and we will investigate your claim.
}

Copyright and moral rights for the publications made accessible in the public portal are retained by the authors and/or other copyright owners and it is a condition of accessing publications that users recognise and abide by the legal requirements associated with these

- Users may download and print one copy of any publication from the public portal for the purpose of private study or research.

- You may not further distribute the material or use it for any profit-making activity or commercial gain

If the publication is distributed under the terms of Article $25 \mathrm{fa}$ of the Dutch Copyright Act, indicated by the "Taverne" license above, 
Maastricht University

Research Centre for Education and the Labour Market | ROA

\section{Skills and the graduate recruitment process: Evidence from two discrete choice experiments}

Martin Humburg

Rolf van der Velden

\section{ROA Research Memorandum}

ROA-RM-2014/2

Research Centre for Education and the Labour Market Maastricht University

P.O. Box 616, 6200 MD Maastricht, The Netherlands

$\mathrm{T}+31433883647 \mathrm{~F}+31433884914$

secretary-roa-sbe@maastrichtuniversity.nl www.roa.nl 


\title{
Skills and the graduate recruitment process: Evidence from two discrete choice experiments
}

\author{
Martin Humburg \\ Rolf van der Velden \\ ROA-RM-2014/2* \\ January 2014
}

Research Centre for Education and the Labour Market

Maastricht University

P.O. Box 616, 6200 MD Maastricht, The Netherlands

$\mathrm{T}+31433883647 \mathrm{~F}+31433884914$

secretary-roa-sbe@maastrichtuniversity.nl

www.roa.nl

\footnotetext{
* The ROA Research Memorandum Series was created in order to make research results available for discussion, before those results are submitted for publication in journals.
} 


\section{Abstract \\ Skills and the graduate recruitment process: Evidence from two discrete choice experiments**}

In this study we elicit employers' preferences for a variety of CV attributes and types of skills when recruiting university graduates. Using two discrete choice experiments, we simulate the two common steps of the graduate recruitment process: 1 ) the selection of suitable candidates for job interviews based on CVs, and 2) the hiring of graduates based on observed skills. We show that in the first step, employers attach most value to CV attributes which signal a high stock of occupation-specific human capital indicating low training costs and short adjustment periods; attributes such as relevant work experience and a good match between the field of study and the job tasks. In line with the preferences in the first step, employers' actual hiring decision is mostly influenced by graduates' level of professional expertise and interpersonal skills. Other types of skills also play a role in the hiring decision but are less important, and can therefore not easily compensate for a lack of occupation-specific human capital and interpersonal skills.

JEL classification: I21, J24

Keywords: graduates, employers, skills, employability, recruitment, stated choice

Martin Humburg

ROA

P.O. Box 616

NL-6200 MD Maastricht

The Netherlands

m.humburg@maastrichtuniversity.nl
Rolf van der Velden

ROA

P.O. Box 616

NL-6200 MD Maastricht

The Netherlands

r.vandervelden@maastrichtuniversity.nl

** This paper and its other versions have benefited from discussions at the Employers' Perspective on Graduate Employability in Europe testing seminar at the EU Commission in Brussels, the Advances in Latent Variables conference in Brescia, and the Transitions in Youth conference in Berlin. We would like to express thanks to Annelore Verhagen for her assistance with this study. The project on which this study is based was made possible through financial support from the European Commission.

The authors wish to thank Andries de Grip and Raymond Montizaan for their helpful comments on an earlier version of this paper. 


\section{Introduction}

The transition from university to work is a pivotal phase in graduates' lives. Graduates exchange the known world of education for the less familiar world of work. For most graduates, this is the first time they get reliable information on the labour market value of their credentials. Every time a recent graduate applies for a job he or she gets information on whether investments in skills and the observable attributes mentioned on their curricula vitaes (CVs) were worth it in terms of getting the job they have applied for.

Graduates who are concerned about their labour market success will invest in the skills which will enable them to take advantage of promising job opportunities. Similarly, graduates try to acquire observable characteristics, such as a higher educational degree or work experience, which increase their skills and/or reliably signal the skills they have to employers. Often, the decisions which have to be made by students and graduates involve potential tradeoffs. For example, individuals who work alongside their studies to gain work experience may find that they lack the time to get a high grade point average. Others may decide to leave university with a bachelor's degree to get work experience instead of enrolling into a master's programme to get additional education. From a graduate's perspective - but also from a higher education policy perspective - it is important to know which choices increase or decrease graduates' employability from the employers' perspective. Knowing the preferences of employers can inform university students' educational choices and can enable higher education institutions to help graduates acquire the skills they need to be successful in the labour market.

In order to assess the relative importance of observable attributes and types of skills in the recruitment process, we conducted two stated choice experiments among 903 employers in 9 European countries. In the first experiment, respondents were repeatedly presented graduate profiles with information on attributes commonly found on graduate CVs. They were then asked to either choose the profile they would like to invite to a job interview, or to choose none of them. The attributes we focus on in this paper are graduates' degree, the match between their field of study and the job tasks, the amount of relevant work experience they have gained, the study experience abroad they have acquired, their grade point average, and the prestige of their alma mater. We exclude indices such as age, race, or gender as this paper exclusively focuses on attributes which are the outcome of individuals' educational and workrelated investments.

In the second experiment, which directly followed the first, we repeatedly presented respondents with hypothetical profiles containing graduates' proficiency in a selection of skill types. Again, respondents were asked to choose a profile (or none); this time, however, the profile they would hire. The types of skills contained on the hypothetical profiles in the second recruitment step were professional expertise, general academic skills, innovative/creative skills, strategic/organizational skills, interpersonal skills and commercial/entrepreneurial skills.

On the basis of these experiments we are able to estimate employers' preferences for CV attributes in the selection of suitable candidates for job interviews, and for various types of skills in the actual hiring decision. In addition, we are able to draw on a large number of indepth interviews with employers to validate the results and to elicit the rationale behind employers' preferences.

We find that employers prefer hiring graduates with higher levels of professional expertise - content-specific knowledge and skills needed to solve occupation-specific problems. Accordingly, employers' selection of graduates for job interviews is most influenced by CV attributes signalling a high stock of occupation-specific human capital, such as a good match 
between the field of study and the job tasks, and relevant work experience. We also find that interpersonal skills are as important to graduates' chances of getting the job as professional expertise.

The contribution of this paper is twofold. First, we are able to shed further light on the recruitment behaviour of employers and the value they attach to various attributes commonly found on applicants' CVs when selecting suitable candidates for job interviews. Second, this paper investigates the relative importance of different types and levels of skills in employers' decision to hire a graduate. We provide important insights with regard to the types of skills which increase graduates' employability.

The remainder of this paper is structured as follows: section 2 reviews the literature on the role of skills in graduates' transition from university to work. Section 3 presents the data and methodology of the study and section 4 the econometric model used to estimate employers' preferences. In section 5 we present the results of the first stated choice experiment, the results of the second stated choice experiment in section 6 . We then draw conclusions in section 7 .

\section{Literature review and theoretical framework}

Rational, profit-maximizing employers hire graduates on the basis of their human capital. Becker (1962) thinks of human capital as the stock of knowledge and skills which enters individuals' (and firms') production function directly. Others conceptualize it as the capacity to adapt to disequilibrium situations such as technological change (Nelson \& Phelps, 1966; Schultz, 1975), or as attitudes towards work and hierarchical settings (Bowles \& Gintis, 1976). Both cognitive and non-cognitive skill endowments contribute to individuals' human capital stock and consequently to their productivity (Heckman, Stixrud \& Urzua, 2006).

When selecting candidates for job interviews, employers face the challenge that human capital is not perfectly observable. Often, employers must rely on limited information contained on CVs to assess the value of job applicants to the firm. Employers will therefore exploit a correlation between productivity and observable characteristics, such as the degree or grade point average, to make inferences about applicants' productivity. The signalling value of the observable characteristic to employers will depend on their demand for the type of skill associated with the signal, and the differing cost structure between high and low skilled graduates (Spence, 1973). The greater the difference of the costs associated with obtaining a particular credential between low and high skilled graduates, the higher the credential's signalling value will be.

Given the very negative social consequences for the groups concerned, a substantial part of the literature on employers' use of observable characteristics as signals in the recruitment process focuses on statistical discrimination against particular groups of applicants, such as older applicants or applicants belonging to particular ethnic or religious minorities (Phelps, 1972; Aigner \& Cain, 1977; van Beek, Koopmans \& van Praag, 1997; Arrow, 1998; Altonji $\&$ Pierret, 2001). Our paper deviates from this line of research in that it explores the signalling value of credentials which are the result of individuals' educational or work-related investments. Furthermore, our study focuses only on the labour market of the highly skilled.

Studies based on graduate survey data find that graduates' chances of securing a graduatelevel job are indeed associated with observable characteristics such as the degree, work experience, grades or study experience abroad (Allen \& van der Velden, 2001; Mason, Williams \& Cranmer, 2009; Allen \& van der Velden, 2011). However, these studies do not provide an analysis of the relative importance of these $\mathrm{CV}$ attributes in the recruitment process. To our knowledge, our study is the first which investigates the relative importance of investment-related CV attributes commonly found on graduate CVs from the employer 
perspective. What is more, by substantiating the results from the experiment with the findings of in-depth interviews with some of the respondents, we are able to shed light on the motivation behind employers' preference for graduates with particular CV attributes.

In addition to examining the signalling value of $\mathrm{CV}$ attributes, this paper investigates the relative impact different types and levels of skills have on graduates' chances of getting a graduate-level job. Differences in the importance of types of skills are based on the idea that economically important skills are not unidimensional and that the extent to which skills are productive depends on the match between workers' skills and the requirements of the job (Sattinger, 1993; Hartog, 1992). Graduates' skill profiles differ with respect to their emphasis on particular types of skills, such as interpersonal, commercial or professional skills. Their chances of securing the job they are applying for therefore depend on the importance of particular types of skills for performing the job tasks. In an analysis of the demand for engineering and science graduates in the UK Mason $(1998,1990)$ identifies work readiness the knowledge, skills and commercial understanding which make graduates deployable soon after hiring - as one of the most important hiring criteria used by employers. In support of this finding Heijke, Meng and Ris (2003) show that a high level of field-specific skills is positively related to graduates' chances of finding a job which matches their field of study. Other studies, however, point to the importance of interpersonal and other transferable skills for graduates' employability. Autor, Levy and Murnane (2003), for example, argue that computers substitute routine analytical and interactive tasks but strongly complement nonroutine analytical and interactive tasks. They subsequently show for the US that the declining price of computer capital in recent decades raised the relative demand for workers who have a comparative advantage in the ability to combine analytic and interactive tasks. Moreover, Biesma et al. (2007) show that for Dutch master-level graduates in the field of public health, problem-solving skills, creativity and interpersonal skills are more important than flexibility and public health knowledge. For the UK, Felstead et al. (2007) find that problem-solving, communication and persuasion skills are rewarded over and above the premium of education and training. Our study attempts to contribute to the literature by identifying employers' preference for various types of skills in various occupational fields and several European countries.

Besides investigating the relative importance of different types of skills, we also explore the effect of the skill level on graduates' chances of getting hired. Based on the findings of earlier studies which suggest that the occupational production function with respect to individuals' skill level is logistic or concave (Knight, 1979; Borghans and de Grip, 2000; van der Velden, 2011), we expect decreasing marginal returns to skills with regard to graduates' employability.

We simulate both stages of the graduate recruitment process using two stated choice experiments. The use of stated choice experiments to estimate respondents' preferences originated in market research (Cattin\& Wittink, 1982; Carroll \& Green, 1995) but is increasingly being applied in various fields of economics such as transport economics, health economics and labour economics (Louviere, Hensher \& Swait, 2000; Ryan, 2004; van Beek, Koopmans \& van Praag, 1997; Biesma, Pavlova, van Merode \& Groot, 2007; Borghans, Romans \& Sauermann, 2010; Pouliakas \& Theodossiou, 2010; Eriksson, Johansson \& Langenskiöld, 2012). The recent increase in the use of stated choice experiments in economics can be attributed in part to recent studies dispelling doubts that stated preferences reliably predict real market behaviour, and showing that parameter estimates based on stated preference data match those based on revealed preference data quite well (Louviere et. al, 2000). With respect to our study, using hypothetical graduate profiles in the experiment enables us to estimate the relative importance of various types of skills without the costly collection of data containing both graduates labour market outcomes and objective measures 
of skills. Moreover, even if we had objective measures of graduates' skill profile estimation results would be biased if some of the types of skills were not used as selection criteria by employers due to the difficulty of reliably assessing them during job-interviews. By assuming that graduates' proficiency in the types of skills presented on the hypothetical profiles have been assessed equally well, we can estimate the demand for skills regardless of whether these skills can be assessed reliably in real-world job interviews.

\section{Data and methodology}

The experiments were conducted in June and July 2012 in nine European countries (Czech Republic, France, Germany, Italy, Poland, Spain, Sweden, The Netherlands and the United Kingdom). Individuals registered on consumer panels of a large international market research organization were invited to participate in an online survey, not knowing its subject. Filtering questions made sure that only individuals who had been involved in recruiting a higher education graduate in the past five years were eligible to participate in the experiments. In those countries with a binary tertiary education system, 'higher education graduate' was explicitly defined as someone who graduated from a university, and explicitly excluded graduates from universities of applied sciences.

Our study focuses on the recruitment of graduates in a selected number of occupational fields. In many occupational fields, recruitment is to a large extent governed by legally binding credentials. As we did not want our study to be confounded by legal requirements, we excluded professions in health and welfare as well as education and focused on seven occupational fields where most of the remaining graduates find work: Electro-technology, Engineering, Financial services, ICT, Legal services, Media and Communication, and Policy and Organization. Respondents who had not recruited a graduate to fill positions in one of these occupational fields in the last five years were excluded from the survey. Table 1 shows the most important sample descriptives.

$20.2 \%$ of the panel members who received an e-mail responded to the invitation to participate in the survey. This number is not a response rate in the usual sense as data collection in each country was halted as soon as 100 employers had completed the survey. $56.8 \%$ of individuals passed the first filter question (involved in recruiting higher education graduates in the past 5 years), and $71.2 \%$ of those passing filter 1 passed filter 2 (involved in recruiting in one of the 7 occupational fields). $68.6 \%$ of those passing all filter questions completed the survey. Overall, we collected responses from 903 employers. In each of the two experiments, these 903 employers made 10 choices, so that 9030 choices per experiment were observed.

\section{[Table 1]}

Before starting the first choice experiment, respondents were asked to imagine a situation in which they recruit a recent higher education graduate in the occupational field they indicated to be recruiting for. Respondents were instructed that the vacancy they are recruiting for in the experiment is a full-time junior position which can be characterized as structural in the sense that it has a longer time horizon and represents an investment for the organization. Seasonal work and short-term replacement positions were excluded. Respondents were told that when choosing the graduate profiles in the experiment they should think of a position in their organization that has these characteristics, and to keep the same position in mind for the entire exercise. 
In the first experiment, only CV attributes which are the result of graduates' human capital investment were included, excluding indices such as age, gender, ethnicity, beauty or religion used in other studies (van Beek et al., 1997; Eriksson et al. 2012).

The following common attributes and their levels are included in the profiles of the first experiment:

1) Degree: Bachelor's degree, Master's degree, Doctorate.

2) The match between the field of study and the job tasks: field of study matches job tasks completely, field of study related to job tasks but no exact match, field of study unrelated to job tasks.

3) Relevant work experience: no, 1 year, 2 years

4) Study abroad: no, partly, entirely

5) Grade Point Average: below average, average, above average, upper $10 \%$

6) Prestige/reputation of university: average, high

7) Starting salary: $25 \%$ below average, $10 \%$ below average, average for this position, $10 \%$ above average for this position, $25 \%$ above average for this position

We restricted the number of attributes to seven in order to limit the information processing burden on respondents. The degree levels used are the typical levels differentiated in higher education. National equivalents of these levels were used in the various translations of the master questionnaire. The three levels referring to the match between the field of study and the job tasks-attribute resemble those commonly used in graduate surveys, indicating that the match is complete, incomplete or non-existent. We deliberately limited the number of years of work experience to two years, reflecting our intention to measure employers' preferences for recent graduates. Study experience abroad was taken up as this attribute is increasingly common in the European context. Grade point average was included in four levels, whereas we included the upper $10 \%$ level to explore whether there is a return to belonging to the top $10 \%$ of the reference group beyond that of having above average grades. The prestige or reputation of the university was taken up as a two level attribute to see whether enrolling into a university with high prestige or reputation, rather than an average university, has an impact on graduates' chances to get invited to a job interview. Starting salary was taken up as an attribute to have a measure of labour costs in the model which may be used to calculate employers' willingness to pay for CV attributes and their levels.

A shortcut randomized design was used to generate the hypothetical graduate profiles (Sawtooth Software, 2000). With this type of design, profiles are constructed using the least often previously used attribute levels for a particular respondent. As a result, the occurrence of attribute levels is balanced (see table A1 in the Appendix).

In the second stage of the survey, we use a discrete choice experiment to elicit employers' preferences for particular skills in the actual hiring decision. We here include six types of skills and the starting salary. Respondents were told that in the first step they had selected and invited a pool of candidates who all seem equally suitable to do the job the respondent was recruiting for, indicating that in this experiment, candidates only differ with regard to the skills included in the profiles. Respondents were instructed that all candidates had been sent to an assessment centre which had thoroughly tested their skills. The information provided on the profile presented the results from this assessment centre, containing the graduates' skill level in the following six domains: ${ }^{1}$

1. The selection of these six types of skills is based on a review of the literature on the skills demanded of higher education graduates in today's workplaces performed by Humburg and van der Velden (2013). 
1) Professional expertise: content-specific knowledge and skills needed to solve occupation-specific problems

2) General academic skills: skills which one typically associates with higher education yet which are not occupation-specific, such as analytical thinking and reflectiveness.

3) Innovative/creative skills: the ability to come up with new ideas and to approach problems from a different angle

4) Strategic/organizational skills: the capacity to think strategically and act in the interest of their organization.

5) Interpersonal skills: ability to work in a team and to communicate and cooperate effectively with diverse colleagues and clients.

6) Commercial/entrepreneurial skills: ability to identify commercial risks and opportunities and being cost-aware.

The skill levels presented on the profiles were whether graduates belonged 1) to the top 25\%, 2) to the average, or 3) to the bottom $25 \%$ of their reference group. For the purpose of readability and comprehensibility we will refer to these levels as high, average and low skill levels.

Respondents were provided with the definitions of the six types of skills before running the choice experiment. In addition, by scrolling over the skill type, they were able to recall the definition of all types of skills at any time during the experiment. The meaningfulness and appropriateness of these types of skills in the context of the recruitment process had been tested with a small sample of human resources personnel before the study started. The tested individuals confirmed the relevance of these types of skills for this study.

[Figure 2]

In order to be able to examine the heterogeneity of preferences during data analysis the following background information on respondents was collected: respondents' role in the organization (general management, HR, specific recruiter, other), respondents' role with regard to recruitment process (responsible, involved), the occupational field they are recruiting for, the economic sector of the firm, the number of graduates whose recruitment respondents had been responsible for or involved in in the past 5 years, the proportion of graduates in the firm, and firm size and the scale of the market the firm is operating on (local, regional, national, international).

A total of 110 in-depth interviews (10 interviews in each of the nine European countries of the online survey plus Estonia, as well as 10 large multinational corporations) were conducted. In the nine countries where the online experiment was conducted, interviewees were recruited from among its participants. In the other two countries and with respect to the 10 large multinational corporations databases of the market research organization were used to recruit interviewees. Each interview lasted about one hour and included a short version of the experiment to learn about the motivation behind employers' choices.

\section{Econometric Model}

We use the mixed logit model to estimate employers' preference for our selection of CV attributes and types of skills. In our discrete choice experiments, the probability of an alternative (a hypothetical graduate) being chosen depends on its characteristics displayed on the profiles shown to respondents, and the difference between its utility and the utilities of the other three alternatives, including the "none of these" option. A conditional logit framework as developed by McFadden (1974) is appropriate for estimating the relative importance of 
graduate characteristics in these kind of choice settings. The mixed logit model we use in this study is an advanced version of the original conditional logit model. While the mean coefficients estimated by both types of models do not differ qualitatively (not shown here) we apply a mixed logit model as it estimates the standard deviation of the mean coefficients, thereby providing information on the extent to which employers' preferences for particular characteristics differ.

Like any discrete choice model consistent with random utility theory, the mixed logit model assumes that an individual faces a choice amongst $J$ alternatives in each of $T$ choice situations. The model is well explained in Hensher and Greene (2003) and Train (2009), on which the following description is strongly based. In our specification, coefficients that enter utility are treated as varying over individuals but being constant over choice situations for each individual. The utility that individual $n$ obtains from alternative $j$ in choice situation $t$ can be written as $U_{n j t}=\beta_{n} x_{n j t}+\varepsilon_{n j t}$, where $x_{n j t}$ is the vector of observed variables (in our case attribute levels), coefficient vector $\beta_{n}$ is unobserved for each $n$ and varies in the population with density $f\left(\beta_{n} \mid \theta^{*}\right)$ where $\theta^{*}$ are the true parameters of this distribution, and $\varepsilon_{n j t}$ is an unobserved random term that is distributed iid extreme value over choice situations, individuals, and alternatives. Conditional on $\beta_{n}$, the probability that individual $n$ chooses alternative $i$ in choice situation $t$ is logit:

$$
L_{n i t}\left(\beta_{n}\right)=\frac{e^{\beta_{n} x_{n i t}}}{\sum_{j} e^{\beta_{n} x_{n j t}}} .
$$

The unconditional probability is the integral of the conditional probability over all possible values of $\beta_{n}$, which depends on the parameters of the distribution of $\beta_{n}$. We specify the density of $\beta_{n}$ to be normal with mean $b$ and covariance $W$. This allows the coefficients to have positive or negative signs for different decision makers. The choice probability under this density becomes:

$$
Q_{n i t}(b, W)=\int \frac{e^{\beta_{n}{ }^{\prime} x_{n i t}}}{\sum_{j} e^{\beta_{n} x_{n i t}}} \phi\left(\beta_{n} \mid b, W\right) d \beta_{n} .
$$

where $\phi\left(\beta_{n} \mid b, W\right)$ is the normal density with mean $b$ and covariance $W . b$ and $W$ are the parameters of interest to be estimated.

If, as normally the case in stated choice experiments, a sampled individual faces a sequence of choice situations, it is the probability of the sequence of observed choices which matters for maximum likelihood estimation. Let $i(n, t)$ denote the alternative that individual $n$ chose in choice situation $t$. Conditional on $\beta_{n}$, the probability that individual $n$ made this sequence of choices is the product of logit formulas:

$$
S_{n}\left(\beta_{n}\right)=\prod_{t=1}^{T}\left[\frac{e^{\beta_{n}{ }^{\prime} x_{n i(n, t) t}}}{\sum_{j} e^{\beta_{n}{ }^{\prime} x_{n j t}}}\right] .
$$

The unconditional probability for the observed sequence of choices is [see Train 2009]: 


$$
P_{n}(b, W)=\int \prod_{t=1}^{T}\left[\frac{e^{\beta_{n} x_{n i(n, t) t}}}{\sum_{j} e^{\beta_{n}{ }^{\prime} x_{n j t}}}\right] \phi\left(\beta_{n} \mid b, W\right) d \beta_{n} .
$$

One of the reasons why mixed logit models have only become a promising tool in data analysis recently is that the integral in (4) necessary for exact maximum likelihood estimation cannot be calculated analytically as it does not have a closed form in general. The integral is approximated through simulation and the simulated log-likelihood function is maximized. For a given value of the parameters $b$ and $W$ (mean and covariance of normally distributed $\beta_{n}$ ) a value of $\beta_{n}$ is drawn from its distribution. Using this draw $S_{n}\left(\beta_{n}\right)$ (equation 3) is calculated. This process is repeated for many draws, and the mean of the resulting $S_{n}\left(\beta_{n}\right)$ 's is taken as the approximate choice probability:

$$
S P_{n}(b, W)=\frac{1}{R} \sum_{r=1}^{R} S_{n}\left(\beta_{n}^{r \mid b, W}\right)
$$

where $\mathrm{R}$ is the number of draws of $\beta_{n}, \beta_{n}{ }^{r \mid b, W}$ is the r-th draw from $\phi\left(\beta_{n} \mid b, W\right)$, and $S P_{n}(b, W)$ is the simulated probability of individual $n$ 's sequence of observed choices. The simulated loglikelihood function is constructed as:

$$
S L L(b, W)=\sum_{n=1}^{N} \ln \left(S P_{n}(b, W)\right.
$$

and the estimated parameters are those who maximize SLL. As noted in Revelt and Train (1998), the log of the simulated probability with a fixed number of draws is not an unbiased estimate of the log of the true probability. However, the bias in $S L L$ decreases as the number of draws increases, and 500 draws commonly generate adequate results. We use 1000 draws in our estimation.

\section{The right $\mathrm{CV}$ for getting invited to the job interview}

Table 2 presents the results of the mixed logit model for graduates' probability of getting invited to a job interview. With the exception of the coefficients for attribute levels "master's degree" and "study abroad entirely", all coefficients are statistically significant. The insignificance of the coefficients for "master's degree" and "study abroad entirely" is a remarkable finding. We will show below that this mean result stems from very opposing views with regard to employers' preferences for these attributes across countries.

[Table 2]

The match between the field of study and the job tasks is one of the most important CV attributes with the mean coefficient of a complete match being 1.137 and that of the field of study and the job tasks being related being 0.709. Having a degree in a field of study which matches the job tasks of the vacancy well gives graduates a decisive advantage over competing applicants who do not have this match. Considering the size of the mean coefficients of the levels of the other attributes, a disadvantage with respect to the match between the field of study and the job tasks will be difficult to compensate for with an advantage with respect to another attribute. The importance of the match between the field of 
study and the job tasks in the recruitment process stems from employers' expectation that graduates with a complete match have higher levels of occupation-specific human capital and will therefore require a shorter adjustment period and less firm-provided training.

A second attribute which can be understood as a measure of graduates' stock of occupation-specific human capital and low training costs is relevant work experience. Relevant work experience has a substantial impact on graduates' probability to get invited to a job interview for a junior position. The mean coefficient of 2 years of work experience, as opposed to none, is similar to that of having a field of study which is related, as opposed to unrelated, to the job on offer (0.711 vs. 0.709). This implies that relevant work experience can to some extent compensate for a lacking match between the field of study and the job tasks; a graduate with 2 years of relevant work experience and an field of study unrelated to the job tasks has a similar probability of being invited to a job interview as a graduate with an incomplete match between the field of study and the job tasks and no relevant work experience, all other attributes being equal. Likewise, a graduate with an incomplete match between the field of study and the job tasks and one year of relevant work experience has a similar probability of being invited to a job interview as a graduate with a complete match and no relevant work experience.

There are obvious decreasing marginal returns to relevant work experience, and the first year increases graduates' chances to get invited to a job interview most. The mean coefficient of the second year of relevant work experience is slightly larger and statistically significantly different from the first. An important difference between the match of field of study and job tasks and relevant work experience is that relevant work experience is not only likely to be a signal of graduates' stock of occupation-specific knowledge and skills, but also general productive factors such as punctuality and attitudes towards hierarchical settings. Employers' expected savings through a shorter adjustment period and lower training costs when recruiting graduates with relevant work experience do therefore not only stem from graduates' higher occupation-specific human capital but also from their greater familiarity with work-life in general.

Remarkably, the standard deviation of 0.775 implies that $23.7 \%$ of employers have a negative coefficient for the 1 year of relevant work experience dummy $[\phi(-0.556 / 0.775)]$.The in-depth interviews suggest that this is not merely an artefact of the assumption of a normally distributed coefficient but that this represents real employer preferences. Whereas most employers prefer graduates who have demonstrated their functioning in work-life and have gathered experience which enables them to "hit the ground running", as one employer expressed it, there are also those employers who prefer "fresh" graduates. These employers argue that individuals who just graduated from university could be integrated into the firm's culture more easily. ${ }^{2}$

Employers' indifference between graduates with a bachelor's and a master's degree in the pooled sample stems from opposing views on the value of these two degrees in different countries. A separate analysis (not shown here ${ }^{3}$ ) reveals that in the UK, graduates with a bachelor's degree are actually preferred over graduates with a master's degree, whereas in the Czech Republic, France, Germany and Poland employers tend to prefer graduates with master's degrees over graduates with bachelor's degrees when it comes to filling vacancies

2. "If you need to train someone in quality control, for example, each company has its own way of working. We prefer to take a young, inexperienced candidate, especially so we can integrate him into a team. It is easier than with a person who has experience." (7, R\&D, Pharmaceutical Industry, France); "The odds are in favour of persons with more experience. On the other hand since this is a junior position we approach it in a way that sometimes it is better to take a person with no experience, to teach him everything, than to accept a person with manners that do not fully correspond to our organization." (3, Finance, Bank, Poland). Quotes always indicate the respondent number as well as the interviewee's occupational field, economic sector and country.

3. We analysed the heterogeneity of preferences using a conditional logit model with attribute dummies interacted with country dummies. The detailed results are available from the authors upon request. 
for junior positions. In Italy and Spain, employers' average preference for master's degrees does not significantly differ from that of employers in the UK, and in the Netherlands and Sweden, employers on average seem to be indifferent about the two degrees.

Graduates' degree is generally seen as an indicator of graduates' skill level and general ability. Yet, degree also correlates with other characteristics relevant for job performance, such as ambition or a hands-on attitude. As a result, the degree is a much broader signal than just one relating to candidates' skill level. In this regard, a good graduate-job match is likely to inter alia depend on the extent to which the skill level required by the job matches the skill level of the graduate, but also the extent to which the career prospects associated with the job match career expectations of the graduate. Consequently, because graduates' degree correlates with other factors such as ambition, it is not self-evident that the employer's best option is recruiting the graduate with the highest degree without taking into account job skill requirements. This becomes apparent when looking at employers' preference for a doctorate whose mean coefficient indicates that the average employer in our sample values a doctorate less than a master's or a bachelor's degree, all other things being equal. This result may be driven by the specific context of our experiment where employers were asked to recruit a graduate for a typical junior position in their organization. The in-depth interviews brought forth several arguments why employers are hesitant to hire a doctorate for a junior position, ranging from doctorates being too ambitious to doctorates being too theoretical in their approach for the average junior position. As recruitment is costly, employers try to avoid hiring graduates who will leave the organization as soon as a better opportunity opens up. Moreover, for some employers the doctorate sends a mixed signal: while employers tend to take for granted that doctorates who apply for junior positions have an elevated level of knowledge, they expect them to have a lower level of other productive factors - such as motivation or self-confidence - than their counterparts who apply for positions which better match their qualification level. This is another reason why some employers are hesitant to consider doctorates for their junior positions. However, the significant standard deviation of the mean coefficient for the doctorate attribute level implies that $38.3 \%$ of employers prefer doctorates over graduates with bachelor's degrees (the coefficient of the dummy indicating a doctorate level is positive for $38.3 \%$ of employers, [1- $\phi(0.357 / 1.195)])$, and that there is a relevant labour market segment for doctorates.

Having above average as opposed to below average grades matters similarly for graduates' chances of getting invited to a job interview, as does having 1 year of relevant work experience. Graduates can compensate for their low grades with relevant work experience, yet graduates with high grades have a higher chance of getting a job.

Marginal returns to grades are decreasing. Employers seem to put the most value on avoiding below average performers. On average, belonging to the upper $10 \%$ of the grades distribution has no additional effect on graduates' probability to be invited to a job interview, over and above the effect of having above average grades. ${ }^{4}$ However, this is not the case for some junior positions with high skill requirements and possibly better career prospects. Some employers interviewed in-depth indicated that they exclusively recruit graduates who are among the best $5 \%$ with regard to grades.

Graduates who have spent some time abroad during their studies are, on average, preferred by employers over graduates who did not gather any study experience abroad. Besides being an indicator of foreign language skills, results from the in-depth interviews strongly suggest that this attribute level is often used by employers as a signal of graduates' independence and resourcefulness. Rather than being decisive for employers' final decision to invite a graduate

4. The difference between the mean coefficients of both attribute levels is not statistically significant. 
to a job interview or not, having some study experience abroad is seen as a nice extra and may tip the balance in the improbable case that two graduates are otherwise identical.

Judging from the pooled sample of employers, having studied entirely abroad does not improve graduates' chances of getting invited to a job interview when compared to graduates who studied exclusively in the home country. There is, however, substantial variation across employers from different countries. ${ }^{5}$ Employers from the UK on average prefer graduates who studied exclusively at home over graduates who followed entire programmes abroad. The average employer in the Czech Republic, France, Germany, the Netherlands, Spain and Sweden seems to be indifferent between graduates who did not go abroad during their studies and graduates who earned a degree abroad, all else being equal. The signalling value of having studied entirely abroad, without specification where precisely the degree was obtained, is only positive in Italy and Poland.

While relevant, the importance of the university's prestige ${ }^{6}$ in the recruitment process is much smaller than that of the match between the field of study and the job tasks or that of relevant work experience. Its impact is, however, comparable to having partly studied abroad or to having above average grades. The prestige of the university is a signal for both the positive self-selection (and thus higher than average ability) of graduates as well as the quality and rigour of education. Many employers interviewed in-depth therefore indicated that they use the prestige of the university to validate grades.

The hypothetical candidate profiles also included the starting salary the graduate would have to be paid when hired. Figure 3 illustrates employers' preference for starting salary. While higher than average starting salaries (almost) linearly decrease employers' preference for candidates, lower than average salaries do not affect employers' selection decision in favour of applicants. An explanation is that employers' preferences reflect institutional arrangements. In Europe, entry salaries for graduates are strongly regulated with minimal room for negotiation. Moreover, negotiation mostly takes place with respect to getting a higher than average salary if justified by a higher level of qualification. Employers may experience the below average starting salary attribute levels as meaningless as it is not feasible to pay one employee less than the institutionalised salary.

\section{[Figure 3]}

If we accept that the parameter estimates for above average attribute levels are a good representation of employers' average preferences for labour costs, we can use these estimates to calculate employers' willingness to pay (WTP) for particular CV attributes. Entering starting salary as a fixed coefficient attribute ensures that it can be used to calculate employers' WTP by simply taking the ratio of attribute and salary coefficients (Revelt and Train, 1998). We take the difference between the coefficients of the average salary level and the $10 \%$ above average salary level as the equivalent of $10 \%$ of the average wage (1.044 $0.600=0.444)$. Employers' willingness to pay for particular CV attribute levels is presented in Table 3.

[Table 3]

5. Here also, we analysed the heterogeneity of preferences using a conditional logit model with attribute dummies interacted with country dummies. The detailed results are available from the authors upon request.

6. It is important to note that the translation to the languages of the 9 countries in which the study was carried out was based on keeping the meaning comparable across countries but adjusting the concept to the national context where necessary. For example, in the UK where university rankings are widely known, used and available, high prestige was translated to high ranking. Referring to ranking would, however, not make much sense in countries like the Netherlands or Germany. In these countries, the concept of reputation was used. This was done as the concept we had in mind for prestige was rather broad, pertaining to the subjective evaluation of a university, not necessarily an objective one. This, however, has to be taken into account when interpreting the results. 
Table 3 shows that on average employers are willing to pay a $12.5 \%$ higher wage for the first year of work experience. The standard deviation of $17.5 \%$ implies that the variation in this willingness to pay is quite substantial. The return to a second year of relevant work experience, over and above that of the first year, is $3.5 \%$ on average. This is very much in line with estimated Mincerian returns to experience of around $4 \%$ for European countries (Bils \& Klenow, 2000). Even after accounting for a steep learning curve in the first year of work, employers' very high willingness to pay for the first year of relevant work experience strongly suggests that work experience is a very important signal of general work readiness. Employers are willing to pay a premium for reducing their risk of hiring someone who is not ready for work-life yet.

Therefore, CV attributes indicating occupation-specific human capital, a shorter adjustment period in the job and a lower need for less firm-provided training have the highest impact on graduates' probability of getting invited to a job interview. In addition, graduates' general ability and capacity to learn as indicated by above average grades - signalling low training costs - have a substantial impact on employers' choices. These results support the view that general human capital can to some extent compensate for specific human capital but not entirely. Other CV attributes, such as study experience abroad or the reputation of the university, are much fuzzier signals of graduates' human capital than the match between the field of study and the job tasks, relevant work experience and grades. They also determine employers' choices but to a much lesser degree.

Interestingly, employers' preferences do not cluster along the lines of categories often used to describe them. In an extended analysis not shown here, we tested whether employers' preferences for $\mathrm{CV}$ attributes differed by firm size, occupational field, nationality and the degree to which the firm is operating on the local, regional, national or international market. ${ }^{7}$ With the exception of graduates' degree and study experience abroad, which were briefly discussed above, no systematic differences were found. This suggests that employers' needs are too diverse to be captured by these variables.

The statistically insignificant coefficient of the none-option dummy implies that employers are indifferent to the choice between inviting no one or a graduate with a relatively weak $\mathrm{CV}$ to the job interview. This may be an indication of the relatively low risk involved in inviting the wrong graduate to a job interview. ${ }^{8}$

\section{Which skills are getting graduates the job?}

Error! Reference source not found. presents the results of the second stated choice experiment of the survey in which we asked respondents to select the graduates they would hire. As shown in Figure 2, graduates now differed with regard to their mastery of different types of skills and could be considered equally suited in all other respects. Therefore, in contrast to the

7. We focus here on employer categories most referred to in the literature. Other background variables we collected, such as the economic sector, the respondent's kind of involvement in the recruiting process, the role of the respondent in the firm, the number of graduate recruitments the respondent was involved in in the past 5 years, or the proportion of graduates in the firm do also not explain the heterogeneity of preferences.

8. The none-option dummy was included in the model assuming a fixed rather than a randomly varying parameter. The coefficient expresses whether employers' utility is higher when not inviting anybody compared to inviting the reference graduate. In our case, this is the graduate with a field of study unrelated to the job task, no work experience, below average grades, a bachelor's degree from a university of average prestige or reputation, no study abroad, and with a starting salary of $25 \%$ above average. In the data, the none-option is operationalized as a graduate profile with all attribute level dummies being 0 and a none-option dummy variable indicating that this is the profile representing the none-option. The none-option dummy is zero for the three hypothetical graduate profiles in the choice set. 
first stage of the experiment, the estimated parameters represent employers' preferences for actual skills, not for some other dimension of human capital.

[Table 4]

As expected, employers always prefer higher skill levels over lower skill levels, no matter what skill type they are considering. There is, however, an obvious asymmetry between the penalty for low ${ }^{9}$ skill levels and the reward for high skill levels: the positive coefficients of the dummies indicating that graduates have a high skill level are always less than half the size, in absolute terms, of the negative coefficients of the dummies indicating that graduates have a low skill level.

With respect to the probability of being hired, the reward for having a high skill level as opposed to an average one is largest for professional expertise and smallest for commercial/entrepreneurial skills. The reward for having a high skill level is second-largest for interpersonal skills, followed by innovative/creative skills and strategic/organizational skills. The reward for a high level of general academic skills lies somewhere in between that of strategic-organizational skills and commercial/entrepreneurial skills. These differences are, however, not always statistically significant. ${ }^{10}$

The penalty ${ }^{11}$ for having low skill levels as opposed to average skill levels is larger than the premium for having high skill levels. Two findings stand out. First, the negative coefficient of the dummy indicating that graduates have a low level of interpersonal skills is largest. While not statistically significantly different from that of professional skills, this result highlights the importance of interpersonal skills in today's workplaces. Employers attach a high value to having at least an average level of interpersonal skills, as one team member with a low level of interpersonal skills can endanger the functioning - and thus productivity - of an entire team.

Second, while the reward for a high level of commercial/entrepreneurial skills is relatively small, the penalty for a low level is relatively large, comparable to that of having a low level of professional expertise. In line with the findings of Mason $(1998,1990)$ employers avoid employees with no commercial intuition or sense of entrepreneurship.

The reward for having a high skill level is similar for innovative/creative and strategic/organizational skills. However, the penalty for having a low skill level is higher for innovative/creative skills. The penalty for having a low level, as opposed to an average one, is similar for strategic/organizational and general academic skills.

The coefficient of the none-option dummy is negative and highly significant, indicating that employers are on average better off hiring a graduate with average levels of all skills and earning the average salary than hiring no one. However, when running a model with the bottom skill level and a starting salary of $25 \%$ above average as the reference category (not

9. Note that in accordance with the attribute levels used in the choice experiment, a graduate has a low skill level if he or she belongs to the bottom $25 \%$ of his or her reference group, and a high level of skill if he or she belongs to the top $25 \%$ of his or her reference group.

10. The coefficient of the dummy indicating a high level of professional expertise is not statistically significantly different from that of interpersonal skills, yet is statistically significantly different from the other coefficients (at the $10 \%$ level for innovative/creative skills). The coefficient of a high level of interpersonal skills is statistically significantly different from that of general academic skills and commercial/entrepreneurial skills (10\% level and 5\% level, respectively) and the reward to a high level of innovative/creative skills as well as strategic/organizational skills is statistically significantly different from that of commercial/entrepreneurial skills (10\% level).

11. We deliberately ran the model with average skills as the reference category to emphasise that there is a penalty for having low skill levels, rather than a reward for having average skill levels. The vast majority of employers interviewed in-depth state that they consider an average skill level as the minimum skill level necessary to come into consideration for the job (note that in our definition, the average level contains $50 \%$ of individuals around the mean). This implies that graduates with skill deficiencies are seriously disrupting the production process, incurring costs to the organization. 
shown here), the none-option dummy is positive and significant, suggesting that it is better to hire no one rather than taking the risk of hiring a graduate without the necessary skills.

Employers' preference for starting salary in the hiring stage is similar to that of the interview stage. Lower than average starting salaries are not associated with a higher probability of being hired. A possible explanation for this result is that paying graduates less than the average is, for the average employer, either not possible (because of institutional agreements) or not desirable (because of disruption in the group), or both. In contrast, employers' preferences for graduates decreases linearly for above average salaries, as shown in Figure 4.

\section{[Figure 4]}

For calculating employers' willingness to pay for skills, we make use of the absolute value of the coefficient of the dummy indicating that the graduate's starting salary is $10 \%$ above the average salary. Table 5 indicates that employers are willing to pay on average a $14.9 \%$ higher salary for a graduate from the upper $25 \%$ of the distribution of professional expertise, compared to a graduate with average professional expertise. The standard deviation of $28.5 \%$ indicates that this willingness to pay varies substantially. For a junior position with an average salary of 30,000 Euro per year the estimates in Table 5 imply an average premium of around 4,500 Euro per year for a graduate belonging to the top $25 \%$ as opposed to the average group with regard to professional expertise.

Employers' willingness to pay for a graduate with low professional expertise is negative, indicating that employers would require compensation for hiring such a graduate. This compensation amounts to about a third of the average salary of a junior position. Taking the example of a junior position with an average salary of 30,000 Euro per year again, the average employer would require compensation of 10,770 Euro per year for hiring a graduate with a low level of professional expertise. This amount can be understood in terms of productivity loss or training costs which have to be spent in order to improve the graduate's skills to average level.

\section{[Table 5]}

Employers attach the highest overall importance to professional expertise and interpersonal skills (the difference between high and low skill levels). Employers expect graduates with high levels of professional expertise to already have been exposed to the occupational challenges occurring most often and to be able to perform the new job tasks quickly. Given the smaller coefficients for general academic skills, the average employer does not seem to perceive professional expertise and general academic skills as perfect substitutes, possibly because the latter implies higher costs for training and a longer adjustment period.

In some instances the influence of innovative/creative skills, strategic/organizational skills and commercial/entrepreneurial skills in the hiring decision is not statistically separable from that of interpersonal skills and professional expertise ${ }^{12}$. They nevertheless tend to form a group of relatively less important skills for labour market entry. The findings from the indepth interviews support this view. Employers acknowledge these three skills as being important, but for further career development rather than for immediate employability.

12. The difference of the coefficients of the dummies indicating a high level of interpersonal skills, innovative/creative skills and strategic/organizational skills is not statistically significant at the $10 \%$ level. The difference of the coefficients of the dummies indicating a low level of professional expertise and commercial/entrepreneurial skills is not statistically significant. 
Depending on the kind of job, these types of skills determine employees' selection for promotion and the ease and speed with which they leave the junior position.

Finally, in additional analyses not shown here ${ }^{13}$ we find no systematic differences in the relative importance of types of skills between employers of different countries, occupational fields, firm size and international market exposure.

\section{Conclusions}

In this study we elicit employers' preferences for a variety of CV attributes and types of skills when recruiting recent university graduates. Using two discrete choice experiments, we are able to show that employers' selection of candidates for job interviews is most strongly influenced by $\mathrm{CV}$ attributes which signal a high stock of occupation-specific human capital indicating short adjustment periods in the job and low training costs. Accordingly, professional expertise is a type of skill strongly influencing the hiring decision. However, we also find that having good interpersonal skills is as important for graduates' employability as having professional expertise. The large impact of interpersonal skills on graduates' chances to get hired confirms earlier studies emphasizing the increasing importance of communication in today's work-life in general, and especially for team productivity (Autor et al., 2003; Biesma et al., 2007; Felstead et al., 2007; Dede, 2010; Allen, 2011; Humburg \& van der Velden, 2013).

Other types of skills and attributes also play a role in the recruitment process but are less important and can therefore not easily compensate for a lack of more specific human capital and interpersonal skills.

Our findings can also be interpreted as evidence for a logistic or concave relationship between skills and productivity. ${ }^{14}$ The productivity loss associated with hiring a graduate with low skills is much larger than the benefits of recruiting a high skilled graduate instead of one with average skills. This suggests that having low skilled workers in the workplace cannot be compensated for by team members with high skills. What is more, our findings suggest that the costs associated with below average performance are so substantial that salary is not an adequate adjustment mechanism. Employers are in general willing to pay average salary for average performance but are unwilling to hire underperforming graduates just because they are cheaper.

The large standard deviations of the estimated mean coefficients imply that there is not the graduate profile which all employers prefer. Rather, employers' demand for skills varies substantially. Some employers may not want to recruit the graduates with the highest skill levels because the job does not require them and they fear that graduates will get bored too quickly. Other employers, and the in-depth interviews confirm this, may not have a strong preference for graduates with high professional expertise because they have the internal training facilities to teach them the occupation-specific knowledge they need. The same employers may therefore put more emphasis on other, more transversal types of skills such as general academic skills because they are an important ingredient for further professional growth. Remarkably, background variables, such as employers' country, occupational field, firm size or international market exposure, explain little of the variance in preferences; the relative importance employers attach to $\mathrm{CV}$ attributes and types of skills does not cluster according to characteristics often used to describe and categorize them - the country differences of preferences for master's degrees and study experience abroad being exceptions. More detailed information on the particular junior positions employers had in mind when

13. Available from the authors upon request.

14. For scatter plots indicating a concave relationship between productivity (the mixed logit coefficients) and skill levels see Figure A1 in the Appendix. 
doing the experiments would be necessary to explain the differences in employers' preferences. This has important implications for individuals intending to maximize their employability. When envisaging employment with a particular employer, graduates need more detailed information on this employer's preferences when making decisions regarding their skill profile. Merely depending on characteristics such as firm size or the sector is insufficient for making optimal choices. Individuals who aim to maximize their average chances on the labour market without having a particular employer in mind do best by investing in their professional expertise and interpersonal skills.

The implications of our results for higher education institutions are similar. Aggregate skill supply should match aggregate skill demand reasonably well, and some graduate skill profiles need to be developed in higher quantity than others. Our findings show that some types of skills are more important for labour market entry while others are more important for individuals' future careers. From the employer's perspective types of skills such as commercial/entrepreneurial skills, innovative/creative skills and strategic/organizational skills are more important and better developed after having acquired a few years of work experience. This suggests that initial higher education should focus on the transmission of occupation-specific knowledge, problem-solving skills, general academic skills and interpersonal skills. Unless it is a central characteristic of a study programme aligned to the needs of particular employers, providing individuals with high levels of commercial/entrepreneurial skills, innovative/creative skills and strategic/organizational skills may not be optimal for graduates' employability. 


\section{References}

Aigner, D. J. \& Cain, G. G. (1977). Statistical Theories of Discrimination in Labor Markets. Industrial and Labor Relations Review, 1977, 30 (1), 175-87.

Allen, J., \& van der Velden, R. (2001). Educational Mismatches versus Skill Mismatches: Effects on Wages, Job Satisfaction, and On-the-Job Search. Oxford Economic Papers, 53(3), 434-52.

Allen, J. (2011). Mobilization of Human Resources. In: J. Allen, \& R. van der Velden (eds.), The Flexible Professional in the Knowledge Society: New Challenges for Higher Education. Dordrecht, Heidelberg, London, New York: Springer, 139-176.

Allen, J. \& van der Velden, R. (2011). The Flexible Professional in the Knowledge Society: Required Competences and the Role of Higher Education. In: J. Allen, \& R. van der Velden (eds.), The Flexible Professional in the Knowledge Society: New Challenges for Higher Education, Higher Education Dynamics, 35. Dordrecht, Heidelberg, London, New York: Springer, 15-53.

Altonji, J.G. \& Pierret, C.R. (2001). Employer Learning and Statistical Discrimination. Quarterly Journal of Economics, 116 (1), 313-50.

Arrow, K.J. (1998). What has Economics to Say about Racial Discrimination? Journal of Economic Perspectives, 12 (2), 91-100.

Becker, G. S. (1962). Investment in human capital: A theoretical analysis. Journal of Political Economy, 70, 9-49.

van Beek, K. W. H., Koopmans, C. C. \& van Praag, B. M. S. (1997). Shopping at the labour market: A real tale of fiction. European Economic Review, 41(2), 295-317.

Biesma, R. G., Pavlova, M., van Merode, G. G., \& Groot, W. (2007). Using conjoint analysis to estimate employers preferences for key competencies of master level Dutch graduates entering the public health field. Economics of Education Review, 26(3), 375-386.

Bils, M. \& Klenow, P. (2000). Does Schooling Cause Growth? American Economic Review, 90(5), 1160-1183.

Borghans, L. \& de Grip, A. (eds) (2000). The Overeducated Worker? The Economics of Skill Utilization. Cheltenham: Edward Elgar.

Borghans, L., Romans, M. \& Sauermann, J. (2010). What makes a good conference? Analysing the preferences of labour economists. Labour Economics, 17(5), 868-874.

Bowles, S. \& Gintis, H. (1976). Schooling in Capitalist America: Educational Reform and the Contradictions of Economic Life. New York: Basic Books.

Carroll, J. D., \& Green, P. E. (1995). Psychometric methods in marketing research: Part I, conjoint analysis. Journal of Marketing Research, 385-391.

Cattin, P., \& Wittink, D. R. (1982). Commercial use of conjoint analysis: A Survey. Journal of Marketing, 46, 44-53.

Dede, C. (2010). Comparing Frameworks for 21st Century Skills. In J. Bellanca, \& R. Brandt (eds.), 21st Century Skills. Bloomington, IN: Solution Tree Press, 51-76.

Eriksson, S., Johansson, P. \& Langenskiöld, S. (2012). What is the Right Profile for Getting a Job? A Stated Choice Experiment of the Recruitment Process. IZA Discussion Papers 6691, Institute for the Study of Labor (IZA).

Felstead, A., Gallie, D., Green, F., \& Zhou, Y. (2007). Skills at Work, 1986 to 2006. Universities of Oxford and Cardiff, ESRC Centre on Skills, Knowledge and Organisational Performance.

Hartog, J. (1992). Capabilities, allocation and earnings. Dordrecht: Kluwer Academic. 
Heckman, J. J., Stixrud, J., \& Urzua, S. (2006). The Effects Of Cognitive and Noncognitive Abilities On Labor Market Outcomes and Social Behavior. Journal of Labor Economics, 24 (3), 411-482.

Heijke, H., Meng, C., \& Ris, C. (2003). Fitting to the job: the role of generic and vocational competencies in adjustment and performance. Labour Economics, 10, 215-29.

Hensher, D., \& Greene, W. (2003). The Mixed Logit model: The state of practice. Transportation, 30(2), 133-176.

Humburg, M., \& van der Velden, R. (2013). What is expected of higher education graduates in the 21st century? Research Memorandum 2013/13, Research Centre for Education and the Labour Market (ROA). Forthcoming in: J. Buchanan, D. Finegold, K. Mayhew, \& C. Warhurst (eds.), Oxford Handbook of Skills and Training. Oxford: Oxford University Press.

McFadden, D. (1974). Conditional Logit Analysis of Qualitative Choice Behavior. In P. Zarembka (ed.), Frontiers in Economics, New York: Academic Press, 105-42.

Knight, J.B. (1979). Job Competition, Occupational Production Functions, and Filtering. Oxford Economic Papers, 31 (2), pp. 187-204.

Louviere, J. J., Hensher, D. A., \& Swait, J. D. (2000). Stated choice methods: analysis and applications. New York: Cambridge University Press.

Mason, G., Williams, G., \& Cranmer, S. (2009). Employability Skills Initiatives in Higher Education: what effect do they have on graduate labour market outcomes? Education Economics, 17 (1), 1-30.

Mason, G. (1998). Diversity and change: The challenges facing chemistry higher education. London: Royal Society of Chemistry/Council for Industry and Higher Education.

Mason, G. (1999). The labour market for engineering, science and IT graduates: Are there mismatches between supply and demand. Research Report No. 112, Department for Education and Employment, London.

Nelson, R., \& Phelps, E. (1966). Investment in Humans, Technological Diffusion, and Economic Growth. American Economic Review, 56 (1/2), 69-75.

Phelps, E. S. (1972). The Statistical Theory of Racism and Sexism. American Economic Review, 62, 659-61.

Pouliakas, K., \& Theodossiou, I. (2010). Measuring the Utility Cost of Temporary Employment Contracts Before Adaptation: A Conjoint Analysis Approach. Economica, 77(308), 688-709.

Revelt, D., \& Train, K. (1998). Mixed Logit With Repeated Choices: Households' Choices Of Appliance Efficiency Level. The Review of Economics and Statistics, 80(4), 647-657.

Rossi, P., McCulloch, R., \& Allenby, G. (1996). On the Value of Household Purchase History Information in Target Marketing. Marketing Science, 15, 321-340.

Ryan, M. (2004). Discrete choice experiments in health care. British Medical Journal, 328, 360-361.

Sattinger, M. (1993). Assignment models of the distribution of earnings. Journal of Economic Literature, 31, 831-880.

Sawtooth Software (2000). An Overview and Comparison of Design Strategies for ChoiceBased Conjoint Analysis. Research Paper Series, Sawtooth Software.

Schultz, T. W. (1975). The Value of the Ability to Deal with Disequilibria. Journal of Economic Literature, 13 (3), 872-76.

Spence, M. (1973). Job Market Signaling. Quarterly Journal of Economics, 87 (3), 355-74.

Train, K. (2009). Discrete Choice Models with Simulation, Cambridge books, Cambridge: Cambridge University Press.

van der Velden, R. (2011). De effecten van betrouwbaarheid van onderwijsdiploma's op arbeidsproductiviteit: toepassing van een simulatiemodel. In: J.Dronkers (ed), Goede 
bedoelingen in het onderwijs: Kansen en missers, boekaflevering Mens en Maatschappij, 27-49. 
Table 1: Sample descriptives

\begin{tabular}{lrr}
\hline \hline & $\mathrm{N}$ & Per cent \\
\hline Country & & \\
Czech Republic & 64 & 7.09 \\
France & 100 & 11.07 \\
Germany & 100 & 11.07 \\
Italy & 100 & 11.07 \\
Netherlands & 147 & 16.28 \\
Poland & 92 & 10.19 \\
Spain & 100 & 11.07 \\
Sweden & 99 & 10.96 \\
United Kingdom & 101 & 11.18 \\
Occupational field & & \\
Electro-technology & 58 & 6.42 \\
Engineering & 186 & 20.6 \\
Financial services & 160 & 17.72 \\
ICT & 171 & 18.94 \\
Legal Services & 133 & 14.73 \\
Media and Communication & 122 & 13.51 \\
Policy & 73 & 8.08 \\
Firm size & & \\
$<$ 20 & 114 & \\
20-49 & 301 & 33.33 \\
50-99 & 140 & 15.50 \\
100-249 & 12.62 \\
>250 & & \\
& & 23.37 \\
\hline \hline
\end{tabular}


Figure 1: Choice set example CV attributes

\begin{tabular}{|c|c|c|c|}
\hline \multicolumn{4}{|c|}{$\begin{array}{l}\text { Of these } 3 \text { candidates, which one would you invite to a job interview? } \\
\text { Remember this is a junior position for a recent higher education graduate }\end{array}$} \\
\hline $\begin{array}{c}\text { Degree: } \\
\text { Bachelor (BA, BSc) } \\
\text { Match of field of study and job tasks: } \\
\text { Field of study related to job tasks but no } \\
\text { exact match } \\
\text { Relevant work experience: } \\
\text { No } \\
\text { Study abroad: } \\
\text { No } \\
\text { Grade Point Average: } \\
\text { Above average } \\
\text { Type of university: } \\
\text { Average ranked university } \\
\text { Starting Salary: } \\
\text { Average for this position }\end{array}$ & $\begin{array}{c}\text { Degree: } \\
\text { Master (MA, MSc) } \\
\text { Match of field of study and job tasks: } \\
\text { Field of study unrelated to job tasks } \\
\\
\text { Relevant work experience: } \\
2 \text { years } \\
\text { Study abroad: } \\
\text { Partly } \\
\text { Grade Point Average: } \\
\text { Average } \\
\text { Type of university: } \\
\text { Average ranked university } \\
\text { Starting Salary: } \\
25 \% \text { below average for this position }\end{array}$ & $\begin{array}{c}\text { Degree: } \\
\text { Doctorate } \\
\text { Match of field of study and job tasks: } \\
\text { Field of study matches job tasks } \\
\text { completely } \\
\text { Relevant work experience: } \\
1 \text { year } \\
\text { Study abroad: } \\
\text { Entirely } \\
\text { Grade Point Average: } \\
\text { Below average } \\
\text { Type of university: } \\
\text { Top ranked university } \\
\text { Starting Salary: } \\
25 \% \text { above average for this position }\end{array}$ & $\begin{array}{l}\text { None of } \\
\text { these }\end{array}$ \\
\hline
\end{tabular}

Figure 2: Choice set example skills

\begin{tabular}{|c|c|c|c|}
\hline \multicolumn{4}{|c|}{ Of these 3 candidates, which one would you hire? } \\
Remember this is a junior position for a recent higher education graduate \\
\hline Starting Salary: & Starting Salary: & Starting Salary: \\
$10 \%$ below average for this position & Average for this position & 10\% above average for this position \\
Professional expertise: & Professional expertise: & Professional expertise: \\
Bottom 25\% & Average & Top 25\% \\
General academic skills: & General academic skills: & General academic skills: \\
Top 25\% & Average & Bottom 25\% & Innovative/creative skills: \\
Innovative/creative skills: & Innovative/creative skills: & Average & None of \\
Top 25\% & Bottom 25\% & these \\
Strategic/organizational skills: & Strategic/organizational skills: & Strategic/organizational skills: & Top 25\% \\
Average & Bottom 25\% & Interpersonal skills: & \\
Interpersonal skills: & Interpersonal skills: & Average \\
Bottom 25\% & Top 25\% & Commercial/entrepreneurial skills: \\
Commercial/entrepreneurial skills: & Commercial/entrepreneurial skills: & Top 25\% & \\
Average & Bottom 25\% & & \\
\hline
\end{tabular}


Attributes with normally distributed coefficients:

Degree:

Bachelor's

Ref.

Master's

Mean coefficient

$0.045 \quad(0.05)$

SD of coefficient

$0.977 * * *$

Doctorate

Mean coefficient

$-0.357 * * * \quad(0.06)$

SD of coefficient

$1.195 * * * \quad(0.08)$

Match of field of study and job tasks

Unrelated

Ref.

Incomplete

Mean coefficient

$0.709 * * * \quad(0.06)$

SD of coefficient

$0.762 * * * \quad(0.10)$

Complete

Mean coefficient

$1.137 * * * \quad(0.07)$

SD of coefficient

$1.228 * * * \quad(0.07)$

Relevant work experience

No

1 year

Mean coefficient

SD of coefficient

2 years

Mean coefficient

$\mathrm{SD}$ of coefficient

Study experience abroad

No

Partly

Mean coefficient

SD of coefficient

Entirely

Mean coefficient

SD of coefficient
Ref.

$\begin{array}{ll}0.556 * * * & (0.05) \\ 0.775 * * * & (0.07) \\ & \\ 0.711 * * * & (0.06) \\ 1.179 * * * & (0.08)\end{array}$

Ref.

$\begin{array}{ll}0.123 * * & (0.04) \\ 0.542 * * * & (0.10)\end{array}$

$-0.004 \quad(0.05)$

$0.795^{* * *} \quad(0.07)$ 
Table 2: Mixed logit model of selecting graduates for a job interview, continued

\section{Grades}

Below average

Ref.

Average

Mean coefficient

SD of coefficient

Above average

Mean coefficient

$0.549 * * * \quad(0.06)$

SD of coefficient

Top $10 \%$

Mean coefficient

$0.579 * * *$

SD of coefficient

$0.790 * * *$

Prestige/reputation of university

Average

Ref.

High

Mean of coefficient

$0.130 * * * \quad(0.04)$

SD of coefficient

$0.457 * * *$

Fixed coefficient attributes

Salary

$25 \%$ below average

$0.935 * * * \quad(0.08)$

$10 \%$ below average

$0.980 * * * \quad(0.07)$

Average

$1.044 * * * \quad(0.07)$

$10 \%$ above average

$0.600 * * * \quad(0.06)$

$25 \%$ above average

Ref.

None

0.083

Standard errors adjusted for 903 clusters (individuals) in parentheses. $* \mathrm{p}$ $<0.05, * * \mathrm{p}<0.01, * * * \mathrm{p}<0.001$. Estimation based on 1000 random draws per iteration. Log likelihood $-9627.26, \mathrm{~N}=36120$. The Wald-test of the joint significance of the attributes with 17 degrees of freedom is 1071.73 and has a p-value $>0.000$. The model has no alternative-specific constants, as is common practice with data from so-called unlabeled choice experiments, where randomly generated alternatives (graduates) have no utility beyond the characteristics attributed to them in the experiment. 
Figure 3: Graphical illustration of salary attribute coefficients displayed in Table 2

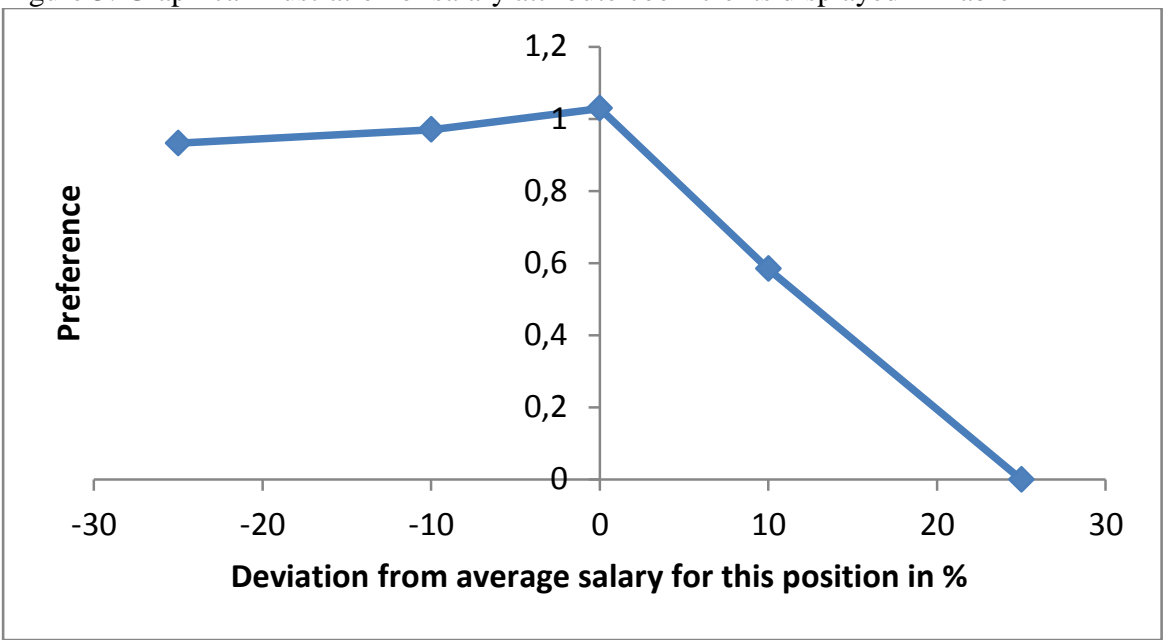

Table 3: Employers' willingness to pay for CV attribute levels

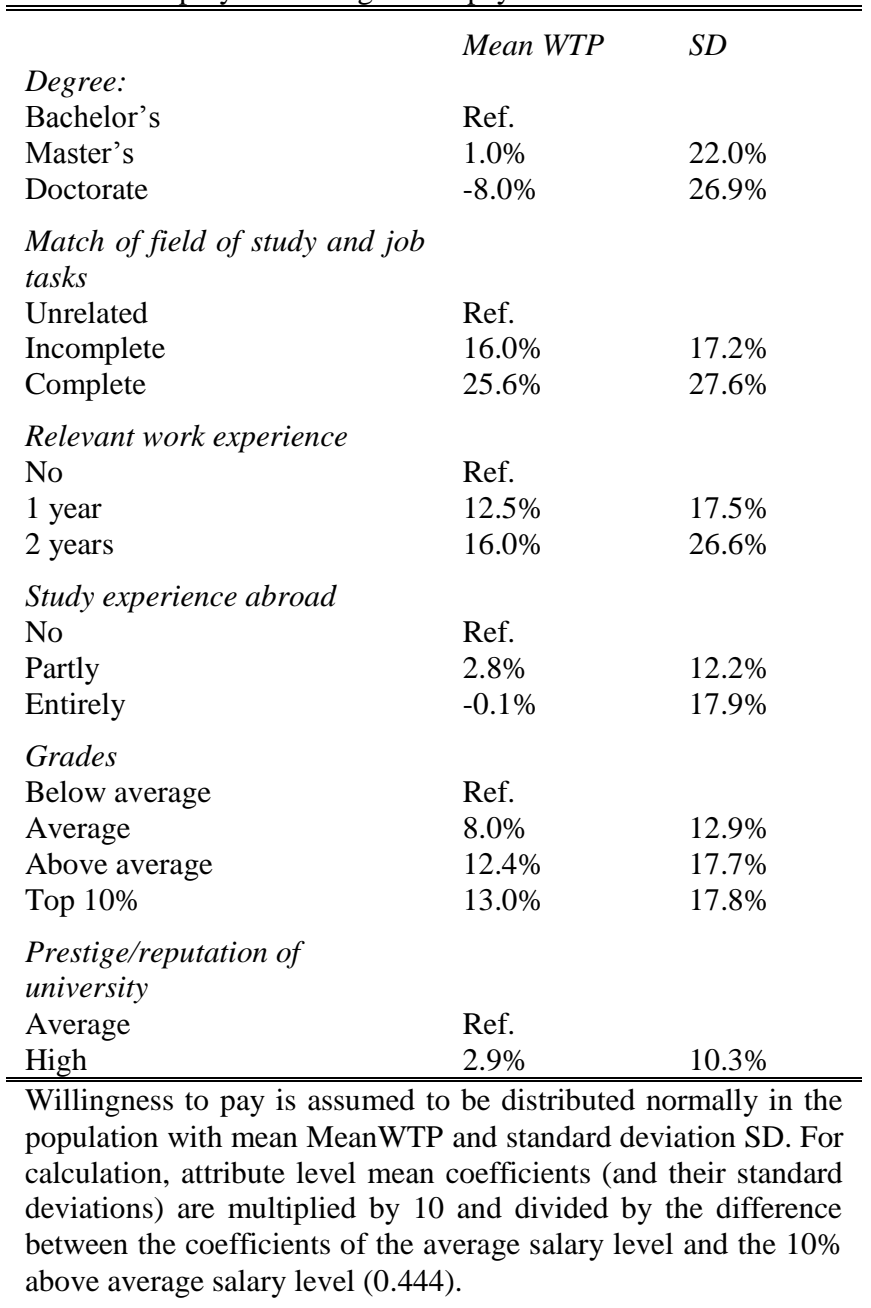


Attributes with normally distributed coefficients:

Professional expertise

High

Mean coefficient

$0.507^{* * *} \quad(0.08)$

SD of coefficient

$0.969^{* * *} \quad(0.12)$

Average

Ref.

Low

Mean coefficient

$-1.219^{* * *} \quad(0.09)$

SD of coefficient

$1.300^{* * *} \quad(0.12)$

General academic skills

High

Mean coefficient

$0.305^{* * *} \quad(0.05)$

SD of coefficient

$0.657^{* * *} \quad(0.07)$

Average

Ref.

Low

Mean coefficient

$-0.900^{* * * *} \quad(0.08)$

SD of coefficient

$1.140^{* * *}$

Innovative/creative skills

High

Mean coefficient

$0.392^{* * * *} \quad(0.05)$

SD of coefficient

$0.660^{* * * *}$

$(0.10)$

Average

Ref.

Low

Mean coefficient

$-1.045^{* * * *} \quad(0.07)$

SD of coefficient

$1.176^{* * *}$

$(0.21)$

Strategic/organizational skills

High

Mean coefficient

$0.376^{* * *} \quad(0.06)$

$\mathrm{SD}$ of coefficient

$0.693^{* * *}$

Average

Ref.

Low

Mean coefficient

$-0.878^{* * * *} \quad(0.07)$

SD of coefficient

$0.859^{* * *} \quad(0.08)$

Interpersonal skills

High

Mean coefficient

$0.422^{* * * *} \quad(0.06)$

SD of coefficient

$0.844^{* * * *}$

$(0.08)$

Average

Ref.

Low

Mean coefficient $\quad-1.329^{* * *} \quad(0.09)$

SD of coefficient $\quad 1.350^{* * *} \quad(0.10)$


Table 4: Mixed logit model of selecting graduates for hiring, continued

Commercial/entrepreneurial skills

High

Mean coefficient $\quad 0.248^{* * *} \quad(0.06)$

SD of coefficient $1.136^{* * * *}$

Average Ref.

Low

Mean coefficient $-1.114^{* * *} \quad(0.07)$

SD of coefficient $\quad 1.105^{* * *} \quad(0.09)$

Fixed coefficient attributes

Salary

$25 \%$ below average $\quad 0.014 \quad(0.07)$

$10 \%$ below average $\quad-0.019 \quad(0.06)$

Average Ref

$10 \%$ above average $\quad-0.340^{* * *} \quad(0.07)$

$25 \%$ above average $\quad-0.874^{* * * *}$

None $\quad-2.515^{* * *} \quad(0.12)$

Standard errors adjusted for 903 clusters (individuals) in parentheses. $* p$ $<0.05, * * p<0.01, * * * p<0.001$. Estimation based on 1000 random draws per iteration. Log likelihood $-8674.02, \mathrm{~N}=36120$. The Wald-test of the joint significance of the attributes with 17 degrees of freedom is 1252.29 and has a p-value $>0.000$. The model has no alternative-specific constants, as is common practice with data from so-called unlabelled choice experiments, where randomly generated alternatives (graduates) have no utility beyond the characteristics attributed to them in the experiment. 
Figure 4: Graphical illustration of salary attribute coefficients displayed in Table 4

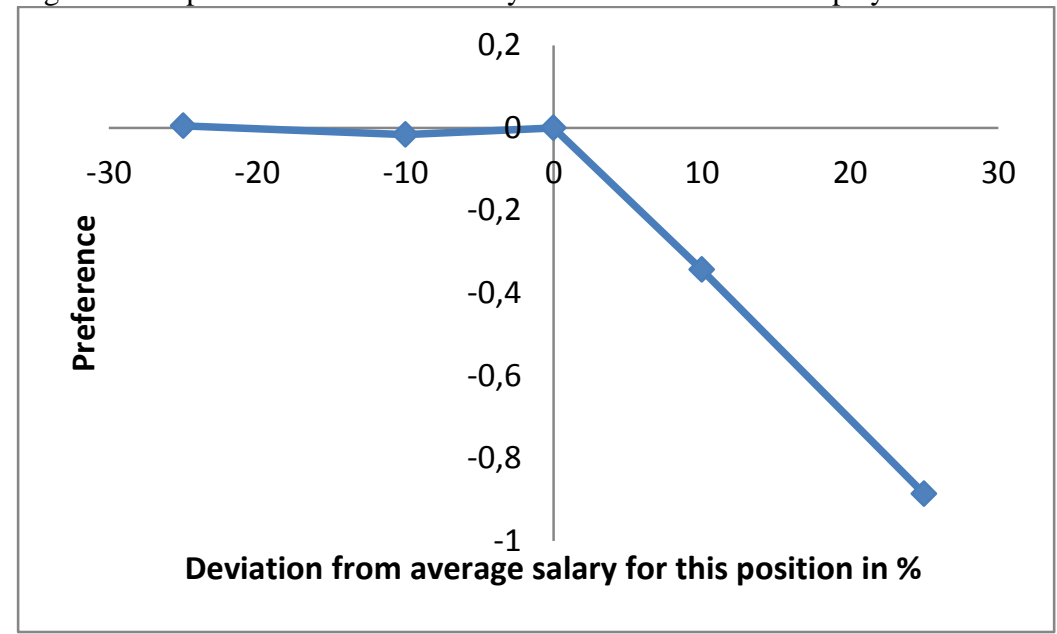

Table 5: Employers' willingness to pay for skills

\begin{tabular}{|c|c|c|}
\hline & Mean WTP & $S D$ \\
\hline \multicolumn{3}{|c|}{ Professional expertise } \\
\hline High & $14.9 \%$ & $28.5 \%$ \\
\hline Average & Ref. & \\
\hline Low & $-35.9 \%$ & $38.2 \%$ \\
\hline \multicolumn{3}{|c|}{ General academic skills } \\
\hline High & $9.0 \%$ & $19.3 \%$ \\
\hline Average & Ref. & \\
\hline Low & $-26.5 \%$ & $33.5 \%$ \\
\hline \multicolumn{3}{|c|}{ Innovative/creative skills } \\
\hline High & $11.5 \%$ & $19.4 \%$ \\
\hline Average & Ref. & \\
\hline Low & $-30.7 \%$ & $34.6 \%$ \\
\hline \multicolumn{3}{|c|}{ Strategic/organizational skills } \\
\hline High & $11.1 \%$ & $20.4 \%$ \\
\hline Average & Ref. & \\
\hline Low & $-25.8 \%$ & $25.3 \%$ \\
\hline \multicolumn{3}{|c|}{ Interpersonal skills } \\
\hline High & $12.4 \%$ & $24.8 \%$ \\
\hline Average & Ref. & \\
\hline Low & $-39.1 \%$ & $39.7 \%$ \\
\hline \multicolumn{3}{|c|}{ Commercial/entrepreneurial skills } \\
\hline High & $7.3 \%$ & $33.4 \%$ \\
\hline Average & Ref. & \\
\hline Low & $-32.8 \%$ & $32.5 \%$ \\
\hline
\end{tabular}




\section{Appendix}

Table A1: Proportional frequencies of attributes in choice set and selected graduate profile

\begin{tabular}{lcc}
\hline \hline & Proportional & Proportional \\
Attribute & $\begin{array}{c}\text { Frequency in } \\
\text { Choice Set }\end{array}$ & $\begin{array}{c}\text { Felected } \\
\text { Graduate Profile }\end{array}$ \\
\hline
\end{tabular}

First Stage (CV attributes)

Degree:

Bachelor's

$0.33 \quad 0.35$

Master's

$0.33 \quad 0.37$

Doctorate

$0.33 \quad 0.28$

Match of field of study and job task

Unrelated

$0.33 \quad 0.21$

Incomplete

$0.33 \quad 0.33$

Complete

$0.33 \quad 0.46$

Relevant work experience

$0.33 \quad 0.25$

1 year

$0.33 \quad 0.35$

2 years

0.33

0.4

Study experience abroad

No

$0.33 \quad 0.33$

Partly

$0.33 \quad 0.35$

Entirely

$0.33 \quad 0.33$

Grades

Below average

$0.25 \quad 0.19$

Above average

0.25

0.25

Average

0.25

0.29

Top 10\%

0.25

0.27

Prestige/reputation of university

Average

$0.5 \quad 0.53$

High

0.5

0.47

Salary

$25 \%$ below average

$0.2 \quad 0.23$

$10 \%$ below average

$0.2 \quad 0.23$

Average

$0.2 \quad 0.23$

$10 \%$ above average

0.2

0.18

$25 \%$ above average 
Table A1: Proportional frequencies of attributes in choice set and selected graduate profile, continued

\begin{tabular}{lcc}
\hline \hline & Proportional & Proportional \\
Attribute & Frequency in & Frequency in \\
& Choice Set & Selected \\
& & Graduate Profile \\
\hline
\end{tabular}

Second Stage (Hiring)

Professional expertise

Top 25\%

$\begin{array}{lc}0.33 & 0.46 \\ 0.33 & 0.34 \\ 0.33 & 0.2\end{array}$

Bottom 25\%

0.33

0.2

General academic skills

Top 25\%

$0.33 \quad 0.41$

Average

0.33

0.35

Bottom 25\%

0.33

0.24

Innovative/creative skills

Top 25\%

$0.33 \quad 0.42$

Average

0.33

0.35

Bottom 25\%

0.33

0.23

Strategic/organizational skills

Top 25\%

$0.33 \quad 0.42$

Average

0.33

0.34

Bottom 25\%

0.33

0.24

Interpersonal skills

Top 25\%

$0.33 \quad 0.44$

Average

$0.33 \quad 0.35$

Bottom 25\%

0.33

0.21

Commercial/entrepreneurial skills

Top 25\%

$0.33 \quad 0.43$

Average

$0.33 \quad 0.36$

Bottom 25\%

0.33

0.22

Salary

$25 \%$ below average

$0.2 \quad 0.22$

$10 \%$ below average

$0.2 \quad 0.21$

Average

$0.2 \quad 0.22$

$10 \%$ above average

$0.2 \quad 0.2$

$25 \%$ above average

0.2

0.15 
Figure A1: Concave relationship between productivity and skill levels

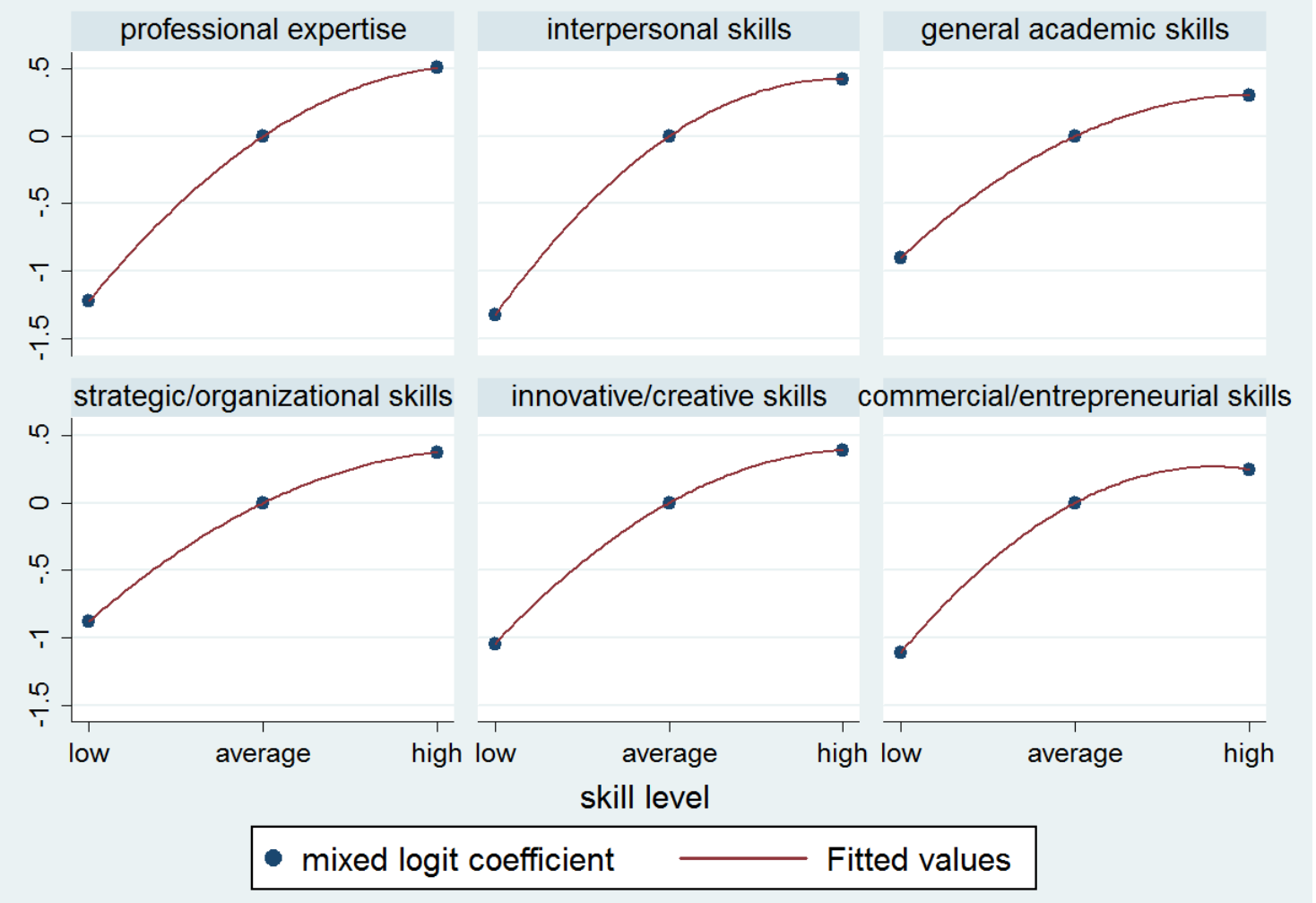

Figure A1 contains scatter plots indicating the concave relationship between productivity (the mixed logit coefficients) and skill levels by type of skill. The fitted values are based on the prediction for the mixed logit coefficient from a regression of the mixed logit coefficient on skill level and skill level squared. 